\title{
ВПЛИВ ЛАКТУЛОЗИ НА СТАН МІКРОБІОТИ ТОВСТОЇ КИШКИ ТА ЛІПІДИЙ СПЕКТР КРОВІ У ХВОРИХ НА СИНДРОМ ПОДРАЗНЕНОЇ КИШКИ У ПОЄДНАННІ $З$ ОЖИРІННЯМ
}

\author{
Г.В. Григорук
}

Івано-Франківський національний медичний університет, кафедра загальної практики (сімейної медицини), фізичної реабілітації та спортивної медицини, м.Івано-Франківськ, Украӥна, ORCID ID: 0000-0002-7858-8444, e-mail: galina.grygoruk81@gmail.com

Резюме. Поширеність синдрому подразненої кишки становить від 12 до 35 \%, а його наявність значно знижує якість життя та вимагає значних затрат на діагностику.

Істотними факторами ризику розвитку синдрому подразненої кишки, окрім недостатньої кількості клітковини в раціоні, стресів, запалення, генетичної схильності є ожиріння та високий індекс маси тіла. Поряд 3 відомими механізмами розвитку варіанту синдрому з закрепами важлива роль належить порушенню мікробіоти товстої кишки.

Мета дослідження - вивчити вплив лактулози на стан мікрофлори товстої кишки та показники ліпідного спектру крові у хворих на синдром подразненої кишки з закрепами в поєднанні з ожирінням.

Обстежено 42 хворих на синдром подразненої кишки з закрепами на тлі ожиріння, розділених на дві групи в залежності від лікування. Хворим першої групи (22 пацієнти) на фоні антигіпертензивної, протиліпідемічної терапії та прокінетика призначали пребіотик лактулозу («Дуфалак»). Обстеженим другої групи (20 пацієнтів) застосовували аналогічну терапію без пребіотика. Діагноз СПКз встановлювали згідно з Римськими критеріями - IV. Діагноз супутньої артеріальної гіпертензії підтверджували даними анамнезу, скаргами, вимірюванням артеріального тиску та даними його добового моніторування. Усім хворим до і після лікування проводили бактеріологічне дослідження вмісту товстої кишки, отриманого за допомогою товстого зонду, та визначали показники ліпідного спектра крові.

Встановлено, що курсове призначення лактулози дещо знижує рівень фірмікутів, не впливаючи на кількість біфідобактерій, підвищує вміст лактобактерій і через них покращує деякі показники ліпідограми.

Ключові слова: синдром подразненої кишки, мікробіота, лактулоза, ожиріння.

Вступ. Згідно з Римськими критеріями IV синдром подразненої кишки визначають як хронічний функціональний розлад кишечника, що характеризується рецидивуючим абдомінальним болем, який виникає і продовжується не менше, як один раз на тиждень за останні три місяці, зв'язаний з дефекацією, змінами частоти і консистенції стільця [1]. Синдром подразненої кишки відрізняється від інших функціональних розладів, зокрема функціонального закрепу, наявністю больового синдрому, а від функціонального здуття кишечника, зміною характеру стільця та больового синдрому [2]. Істотними факторами ризику розвитку СПК, окрім недостатньої кількості клітковини в раціоні, стресів, запалення, генетичної схильності є ожиріння та високий індекс маси тіла. [3].

На більш частий розвиток СПК з закрепами на тлі ожиріння також вказують інші автори [4]. СПК до цих пір залишається найбільш поширеним захворюванням шлунково-кишкового тракту, а ожиріння актуальною проблемою ендокринології. Поширеність СПК становить від 12 до $35 \%$, а у жінок розвивається на 70,0 \% частіше, ніж у чоловіків [5]. Незважаючи на той факт, що СПК не впливає на смертність, можна 3 упевненістю говорити про зниження якості життя та значні затрати на діагностику і лікування.
Поряд 3 генетичною схильністю, психосоціальними факторами, зниженням психоадаптивних механізмів, нерідко відсутністю зовнішньої соціальної підтримки, розладів зв'язку кишкаголовний мозок наступають сенсорні i моторноавакуаторні порушення з формуванням чотирьох його клінічних варіантів [6]. Класифікація СПК в залежності від характеристики стільця передбачає поділ на СПК з закрепами, СПК з діареєю, змішаний тип i некласифікований. Частота СПК з закрепами кінцево не встановлена, але за результатами досліджень C.W. Sobrago et al. [2] становить 15-20\% від частоти цього захворювання. Класифікація хворих на СПК на певні варіанти на основі переважання симптомів з боку кишечника є корисною, оскільки допомагає зосередити лікування на переважаючому, а деколи найбільш несприятливому симптомі [7]. При СПКз у $25 \%$ випадків калові маси відповідають 1 і 2 типам по Брістольській шкалі його форми, характерним є здуття живота, що посилюється у другій половині дня, відчуття неповного звільнення кишечника, болі i дискомфорт в ділянці ануса [8].

Обгрунтування дослідження. Поряд 3 відомими механізмами розвитку даного варіанту СПК розглядається роль змін мікробіоти товстої кишки [9]. Мікробіота товстої кишки, взаємодіючи із її слизовою 
оболонкою, може призводити до зниження бар'єрних функцій та посилювати передачу сигналів 3 просвіту до нервових та імунних центрів, викликаючи функціональні симптоми, зокрема біль [10]. Безпосередньо контактуючи з ентероцитами і колоноцитами біфідо- і лактобактерії стимулюють механізми захисту організму людини, у тому числі зростання швидкості регенерації слизової оболонки, впливаючи на синтез антитіл до власних, але володіючих патогенними властивостями мікроорганізмів, активують фагоцитоз, синтез лізоциму, інтерферонів, цитокінів [11]. Також лактобактерії підтримують рН у товстій кишці на рівні 5,5 - 5,6. Як природний резидент мікрофлори кишечника, лактобактерії здатні змінювати іiі склад і метаболічну активність за рахунок зростання біфідобактерій, кількості рідини в просвіті і регулювати дефекації. Молочнокислі бактерії стимулюють моторику товстої кишки, особливо в поєднанні з харчовими волокнами. Escherichia coli i деякі інші бактерії гальмують перистальтику кишечника, впливають на частоту i амплітуду кишкових скорочень та призводять до розвитку СПКз.

Що стосується ожиріння, то воно асоціюється із зростанням частки фірмікутів та зниження кількості бактероїдів [12]. Також, у хворих на СПКз у поєднанні 3 ожирінням відмічається зниження рівня біфідо- i лактобактерій, зростання концентрації, S.aureus, кишкової палички, а останні якраз і здатні гальмувати перистальтику кишечника [13].

Терапія СПК рекомендована згідно з Римськими критеріями IV залежить від ведучого клінічного симптому, а для лікування констипаційного синдрому рекомендується приймати псилліум, поліетиленгліколь, активатори хлорних каналів і антагоністи гуанілатциклази [14], хоча два останні не зареєстровані в Україні. Часто для лікування СПКз використовується препарат периферичної дії - лактулоза («Дуфалак»), що має високий профіль безпеки та економічну доступність, хоча його вплив на стан мікробіому товстої кишки і показники ліпідного обміну вивченні недостатньо.

Мета дослідження. Вивчити вплив лактулози на стан мікрофлори товстої кишки та показники ліпідограми у хворих на синдром подразненої кишки з закрепами в поєднанні з ожирінням.

Матеріали і методи. Обстежено до і після лікування 42 хворих на синдром подразненої кишки, що розвинувся на тлі ожиріння, розділених на дві групи в залежності від способу терапії. Хворим першої групи (22 пацієнти) на фоні антигіпертензивної («Лізиноприл» по 20 мг, «Амлодипін» по 10 мг та «Індап» по 2,5 мг) та протиліпідемічної терапії (аторвастатин по 20 мг на добу), прокінетика («Домперідон» по 10 мг на добу) призначали пребіотик («Дуфулак») по 30 мл натще. Обстеженим другої групи (20 пацієнтів) застосовували аналогічну терапію без пребіотика. Діагноз СПКз встановлювали згідно з Римськими критеріями - IV. Діагноз супут- ньої артеріальної гіпертензії підтверджували даними анамнезу, скаргами, вимірюванням артеріального тиску та даними його добового моніторування за допомогою апарату «Кардіосенс АД» (виробництво національного космічного університету ім. Н.Е. Жуковського «Україна»).

Усім включеним в дослідження виконано до і після двотижневого лікування бактеріологічне дослідження вмісту товстої кишки, отриманого за допомогою товстого зонду. Матеріал (5-10 мг) забирали стерильною ложечкою та поміщали в стерильні пробірки і закривали пробками. Із отриманого матеріалу не пізніше як через дві години готували гомогенати 3 фізіологічним розчином у розведеннях 1:10 3 послідуючими серійними розведеннями 1:100, 1:1000, 1:10000. По 1 мл отриманих розведень засівали на різні живильні селективні середовища (Ендо, Левіна, Сабуро, Плоскірєва, Блаурококка, молочно-сольовий та кров'янистий агар, середовище Вільсон-Блер, агар 3 коліміцином і налідоксовою кислотою, середовище Гіса). Після різних термінів інкубації чашок із засівами розраховували кількість мікроорганізмів кожного виду в 1 грамі досліджуваного матеріалу за формулою:

$$
\mathrm{K}=\mathrm{E} /(\mathrm{K} \times \mathrm{Vn})(1)
$$

де К - кількість бактерій, Е - сума колоній даного виду у всіх розведеннях, V - об'єм суспензії, що нанесена на чашки Петрі, $\mathrm{n}$ - ступінь розведення.

У всіх обстежених також визначали показники ліпідного спектра крові (рівень загального холестеролу, холестеролу ліпопротеїдів низької та високої щільності; триацилгліцеридів ферментноколориметричним методом на аналітичній модульній тест системі Cobas 6000 Roche Diagnostics (Швейцарія)).

Отримані результати опрацьовували статистично з використанням стандартного пакету програм Statistica 8,0 for Windows та пакету статистичних функцій програми Microsoft Excel. Вірогідність відмінності між залежними і незалежними величинами оцінювали за допомогою $\mathrm{t}$ - критерію Стюдента, a відмінність вважали достовірною при $\mathrm{p}<0,05$.

Результати дослідження та їх обговорення. Нашими попередніми дослідженнями встановлено, що у хворих на синдром подразненої кишки з закрепами, що виник на фоні ожиріння, має місце зниження рівня біфідо- і лактобактерій, зростання концентрації клостридій, St. aureus кишкової палички, грибків роду Candida [15]. Між вираженістю і частотою надмірного бактеріального росту існує тісний зв'язок, а додатковими факторами, що впливають на транзит кишкового вмісту при цьому $є$ періодичні стреси і надлишкова маса тіла. Через відсутність у нашій країні любіпростону і лінаклотиду для лікування СПКз широко застосовується препарат периферичної дії лактулози («Дуфалак»).

Результати впливу лактулози на стан порожнинної мікробіоти товстої кишки подані в таблиці 1. 
Таблиця 1

Динаміка окремих мікроорганізмів порожнини товстої кишки під впливом препарату лактулози у хворих на СПКз на тлі ожиріння

\begin{tabular}{|c|c|c|}
\hline $\begin{array}{l}\text { Таксони мікробіоти і їх популяцій- } \\
\text { ний рівень }\end{array}$ & Базисна терапія & Терапія препаратом лактулози \\
\hline Біфідобактерії & $\frac{5,72 \pm 0,18}{5,70 \pm 0,12}$ & $\frac{5,68 \pm 0,13}{5,47 \pm 0,14}$ \\
\hline Лактобактерії & $\frac{3,52 \pm 0,18}{3,68 \pm 0,14}$ & $\frac{3,56 \pm 0,24}{5,28 \pm 0,16}$ \\
\hline Патогенні стрептококи & $\frac{4,59 \pm 0,12}{4,61 \pm 0,12}$ & $\begin{array}{l}4,68 \pm 0,14 \\
4,65 \pm 0,12\end{array}$ \\
\hline Клостридії & $\begin{array}{l}3,21 \pm 0,33 \\
3,79 \pm 0,09\end{array}$ & $\begin{array}{c}3,30 \pm 0,23 \\
2,54 \pm 0,09 *\end{array}$ \\
\hline Кишкова паличка & $\frac{7,82 \pm 0,34}{7,83 \pm 0,12}$ & $\frac{7,82 \pm 0,32}{6,45 \pm 0,27 \%}$ \\
\hline St. Aureus & $\frac{6,38 \pm 0,17}{6,61 \pm 0,12}$ & $\frac{6,42 \pm 0,16}{4,99 \pm 0,12 \pi}$ \\
\hline St. epidermidis & $\frac{5,30 \pm 0,18}{5,51 \pm 0,01}$ & $\frac{5,29 \pm 0,18}{4,59 \pm 0,09 *}$ \\
\hline Грибки роду Candida & $\frac{4,36 \perp 0,16}{4,12 \perp 0,15}$ & $\frac{4,22 \perp 0,14}{3,66 \perp 0,08 *}$ \\
\hline
\end{tabular}

Примітка: У чисельнику - до лікування, у знаменнику --після

*Різниця статистично достовірна $(\mathrm{p}<0,05)$

Як видно з даних таблиці, під впливом базисної терапії показники порожнинної мікробіоти достовірно не змінювалися, хоча i відмічена тенденція до подальшого зростання кількості клостридій, золотистого стафілокока, тобто бактерій роду Firmicutes.

Під впливом комплексного лікування 3 включенням до базової терапії лактулози відмічено зростання кількості лактобактерій у 1,5 рази. На думку Y. Kadaoka [14], тривалий прийом йогурту 3 підвищеним вмістом лактобактерій сприяє зниженню маси тіла у пацієнтів 3 ожирінням. Комплексна терапія з включенням лактулози сприяла зниженню в мікробіоті товстої кишки кількості клостридій та St. aureus у 1,3 рази, кишкової палички у 1,2 рази. Курсове призначення «Дуфалаку» також сприяло зменшенню в ній грибків роду Candida i St.epidermidis в 1,2 рази. Отримані дані узгоджуються 3 результатами досліджень О. Н. Минушкина [16], який відмітив позитивний вплив лактулози на дисбіотичні зміни та відновлення нормального стільця у 69,2 \% хворих, що отримували лактулозу. Оскільки мікробна контамінація товстої кишки є важливим етіологічним фактором впливу на перистальтику кишечника, викликаючи структурні i функціональні реакції ентеральних нейронів, то покращення іiі складу можна розглядати як один 3 ефектів лактулози. 3 іншого боку деякі автори вважають, що СПК створює добрі умови для розмноження бактерій та їх надмірного росту [6]. У хворих на СПКз співвідношення Bacteroidites / Firmicutes було нижчим, а серед останніх переважали клостридії [17], а число лактобацил було зниженим. Підвищення кількості біфідо- та лактобактерій зменшує можливість розвитку ожиріння та сприяє покращенню показників ліпідного обміну, результати дослідження яких під впливом лактулози подані на рисунку 1.

Встановлено достовірне $(\mathrm{p} \approx 0,05)$ зниження

рівня загального холестеролу та ХЛНЩ і деяке зростання рівня ХЛВЩ при відсутності динаміки триацилгліцеридів. Як вказують К. А. Айтбаєв и соавт. [18], модуляція кишкової мікробіоти під впливом послаблюючих, пре- та пробіотиків може позитивно впливати на перебіг СПК. За даними ж Е. А. Корниенко [19], мікробіота кишечника може корегувати деякі прояви метаболічного синдрому i ожиріння, зокрема рівні холестерину, глюкози, інсуліну.

Висновки. Таким чином, курсове призначення лактулози дещо знижує рівень фірмікутів та не знижує кількість біфідо- і підвищує вміст лактобактерій і через них, можливо, покращує деякі показники ліпідного спектру крові. 
Динаміка окремих показників ліпідного спектру крові під впливом курсового застосування "Дуфалаку"

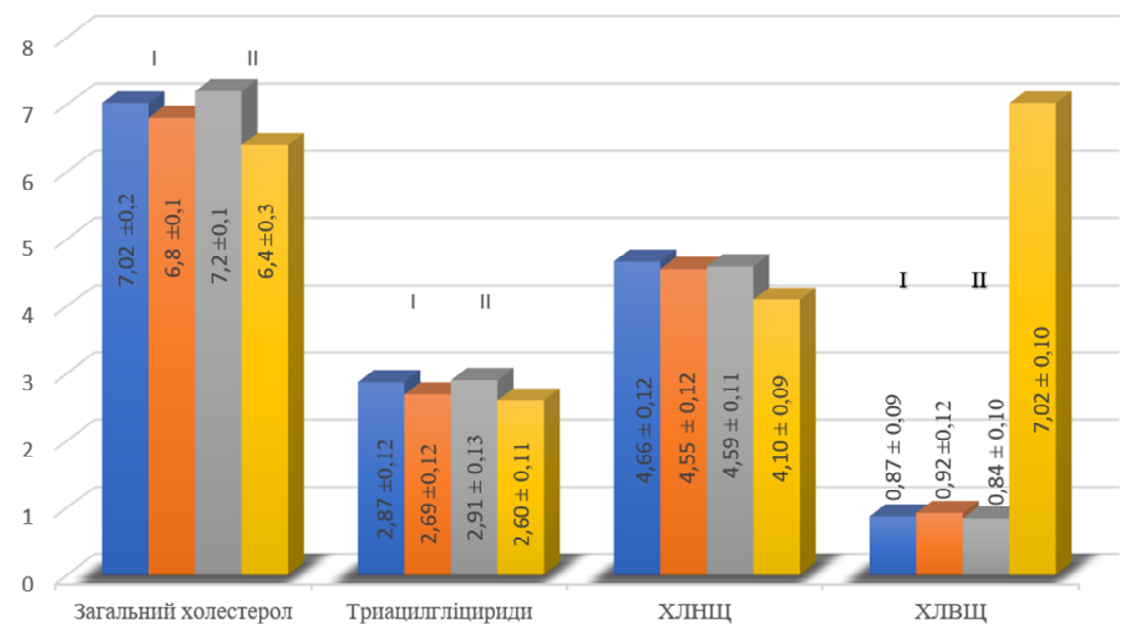

Рис. 1. Динаміка основних показників ліпідного спектру крові під впливом курсового застосування «Дуфалаку»

\section{References:}

1. Lacy BE, Patel NK. Rome Criteria and a Diagnostic Approach to irritable Bowel Syndrome. J. Clin Med, 2017; 6(11):99. Doi: 10. 3390| jcm 611099.

2. Sobrado CW, Correa Netoj JF, Amber R, et al. Diagnostic and treatment of constipation: a clinical update based on the Rome IV criteria. J. Coloproctol. (Rio J.), 2018; 38:2. http://dx.doi.org/10/1016/jcd.2018.02.003.

3. Larussa T, Rossi M, Surari E et al. Use of Complementary and Alternative Medicine by Patients with Irritable Bowel Syndrome According to the Roma IV Criteria: A Single-Center Italian Survey. Medicina (Kaunas). 2019; 55(2):46. doi: 10.3390.

4. Seung - Eun Jung, Nam -Seok Joo, Kyung-Sun Han and $\mathrm{Ky}-\mathrm{Nam} \mathrm{Kim}$. Obesity is Inversely Related to Hydrogen - Producing Small Intestinal Bacterial Overgrowth in Non-Constipastion Irritable Bowel Syndrome. J. Korean Med - Sci, 2017; 32(6):948-953. Doi:10.3346.

5. Moayyedi P, Mearin F, Azpirioz F, Andersen V. Irritable bowel syndrome diagnosis and management: A simplited algorithm for clinical practice. United European Gastroenterology Journal, 2017; 5(6):773-88. Doi 1177/2050640640617731968.

6. Oswiecimska J, Szymlak A, Roczniak W. New insights into the pathogenesis and treatment of irritable bowel syndrome. Adv. Med. Sci, 2017; 62(1):17-30

7. Whitehead WE, Palsson OS, Simren M. Irritable bowel syndrome: What do the new Rome IV diagnostic quidelines mean for patient management? Expert Rewiew of Gestroenterology Hepatology, 2017; 11:4:281-83. doi.org/10/1080/1747124.2017.1292.130.

8. Schmulson MJ, Grossmann DA. What Is New in Roma IV. Journal of Neurogastroenterology and Motility. 2017; 23(2):151-66. https//doi.org/10.5056/jnm.16214.

9. Barbara G, Feinle-Bisset C, Ghoshal UC et al. The Intestinal Microenvironment and Functional Gastrointestinal Disorders. Gastroenterology.2016; P.18. doi:10.1053/j.gastro.2016.02.028.
10. Distrutti E, Monaldi L, Ricci P, Fiorucci S. Gut microbiota role in irritable bowel syndrome: New therapeutic strategies. World J Gastroenterol. 2016; 21;22(7):2219-41. doi: 10.3748/wjg.v22.i7.2219.

11. Shekina M.I. Sindrom razdrazhennogo kishechnika s tochki zreniya praktikuyushego gastroenterologa /Consilium medicum. Gastroenterologiya. - 2018; 1:5457.

12. Ley RE, Turnbaugh PJ, Klein S, Gordon JI. Microbial ecology: human gut microbes associated with obesity. Nature. 2006; 21;444(7122):1022-3.

13. Chamara Basnayake. Treatment of irritable bowel syndrome. Gastroenterologist and Clinical and research fellow. Aust Prescr. 2018; 41(5):145-149. doi: 10.18773/austprescr.2018.044

14. Kadooka Y, Sato M, Imaizumi K et al. Regulation of abdominal adiposity by probiotics (Lactobacillus gasseri SBT2055) in adults with obese tendencies in a randomized controlled trial. Eur J Clin Nutr. 2010; 64(6):636-43. doi:10.1038/ejen.2010.19.

15. Hryhoruk HV, Mishchuk VH, Tserpiak NV. Zminy tovstokyshkovoho mikrobioma ta pokaznyky lipidnoho spektra krovi u khvorykh na syndrom podraznenoi kyshky u poiednanni $\mathrm{z}$ ozhyrinniam. Bukovynskyi medychnyi visnyk. 2019; 23(1)32-38

16. Minushkin ON. The possibility of using lactulose in gastroenterological practice. Consilium medicum. Gastroenterology. 2012; 2:80-85.

17. Undseth R, Berstad A, Valeur J. Systemic symptoms in irritable bowel syndrome: An investigative study on the role of enterocyte disintegrity, endotoxemia and inflammation. Mol Med Rep. 2016;14(6):5072-5076. doi:10.3892/mmr.2016.5878.

18. Ajtbaev KA, Murkamilov IT, Fomin VV, Yusupov FA. Syndrome of irritated intestines: pathophysiological role of intestinal dysbiosis and opportunities for its modulation. Medical news of north Caucasus. 2018; 13:1.1 
19. Kornienko EA. Modern views on the relationship of obesity and intestinal microbiotes. Pediatr. 2013; IV:3 ISSN 2079-7850.

УДК 615.281+616.345+577.115+612.1+616-056.52

ВЛИЯНИЕ ЛАКТУЛОЗЫ НА СОСТОЯНИЕ МИКРОБИОТЫ ТОЛСТОЙ КИШКИ И ЛИПИДНЫЙ СПЕКТР КРОВИ У БОЛЬНЫХ СИНДРОМОМ РАЗДРАЖЕННОЙ КИШКИ В СОЧЕТАНИИ С ОЖИРЕНИЕМ

\section{Г.В. Григорук}

Ивано-Франковский начиональньй медицинский университет, кафедра общей практики (семейной медицины), физической реабилитации и спортивной медиииньl., г. Ивано-Франковск, Украина,

ORCID ID: 0000-0002-7858-8444,

e-mail: galina.grygoruk81@gmail.com

Резюме. Распространенность синдрома раздраженной кишки составляет от 12 до $35 \%$, а его наличие значительно снижает качество жизни и требует значительных затрат на диагностику.

Существенными факторами риска развития синдрома раздраженной кишки, кроме недостаточного количества клетчатки в рационе, стрессов, воспаления, генетической предрасположенности также являются ожирение и нарушение микробиоты толстой кишки.

Цель исследования - изучить влияние лактулозы на состояние микрофлоры толстой кишки и показатели липидограммы у больных синдромом раздраженной кишки с запорами в сочетании с ожирением.

Обследовано 42 больных с синдромом раздраженной кишки с запорами на фоне ожирения, разделенных на две группы в зависимости от лечения. Больным первой группы (22 пациента) на фоне антигипертензивной, протилипидемичнои терапии и прокинетика назначали пребиотик лактулозу. Обследованным второй группы (20 пациентов) применяли аналогичную терапию без пребиотика. Диагноз СРК устанавливали согласно Римским критериям - IV. Диагноз сопутствующей артериальной гипертензии подтверждали данными анамнеза, жалобами, измерением артериального давления и показателями его суточного мониторирования. Всем больным до и после лечения проводили бактериологическое исследование содержимого толстой кишки, полученного с помощью толстого зонда, и определяли показатели липидного спектра крови.

Установлено, что курсовое назначение лактулозы несколько снижает уровень фирмикутов, не влияя на количество бифидобактерий, повышает содержание лактобактерий и через них улучшает некоторые показатели липидограммы.

Ключевые слова: синдром раздраженной кишки, микробиота, лактулоза, ожирение.
UDC 615.281+616.345+577.115+612.1+616-056.52

INFLUENCE OF LACTULOSIS ON THE GUT MICROBIOTA AND LIPID BLOOD SPECTRUM IN PATIENTS WITH IRRITABLE BOWEL SYNDROME COMBINING WITH OBESITY

\author{
G.V. Grygoruk
}

Ivano-Frankivsk National Medical University, Department of General Practice (Family Medicine), Physical Rehabilitation and Sports Medicine, Ivano-Frankivsk, Ukraine, ORCID ID: 0000-0002-7858-8444, e-mail: galina.grygoruk81@gmail.com

Abstract. The prevalence of irritable bowel syndrome is between $12 \%$ and $35 \%$, and its presence significantly reduces the quality of life and requires significant cost of diagnosis.

Excessive risk factors for the development of irritable bowel syndrome, in addition to lack of fiber in the diet, stress, inflammation, genetic predisposition are obesity and a high body mass index. Along with the known mechanisms of developing a variant of the syndrome with constipation, an important role belongs to the violation of the microbiota of the colon.

The purpose of the study is to investigate the effect of lactulose on the state of the colon microflora and lipid profile of blood in patients with irritable bowel syndrome with constipation in combination with obesity.

Materials and methods. We examined 42 patients with irritable bowel syndrome with constipation on the background of obesity, divided into two groups depending on treatment. Patients in the first group (22 patients) received prebiotic lactulose ("Dufalak") in addition to antihypertensive, anti-lipidemic therapy and prokinetics. The second group (20 patients) was treated with similar therapy without prebiotics. Diagnosis of irritable bowel syndrome was established according to Roman criteria - IV. The diagnosis of arterial hypertension was confirmed by data from anamnesis, complaints, blood pressure measurements and daily monitoring of blood pressure data. All patients had a bacteriological examination of the contents of the colon obtained using a thick probe before and after treatment. Indicators of the lipid spectrum of blood (total cholesterol, cholesterol of low and high density lipoprotein, triacylglycerides were determined by the enzymecolorimetric method for all patients.

Results. Under the influence of basic therapy, the parameters of intestinal microbiota did not significantly change. Under the influence of complex treatment with the addition of lactulose to the base therapy, there was an increase in the amount of lactobacilli in 1,5 times. Integrated therapy with the inclusion of lactulose contributed to a decrease in the intestinal microbiota of clostridium and St. aureus in 1,3 times, E. coli in 1,2 times. Course of lactulose application also contributed to the reduction of Candida and St.Epidermidis in 1.2 times. Since microbial colon contamination is an important etiological factor affecting intestinal peristalsis, causing structural and functional reactions of enteral neurons, its improvement can be considered as one of the effects of lactulose. 
The increase in the number of bifidobacteria and lactobacilli decreases the possibility of obesity and promotes lipid metabolism. Under the influence of the course of lactulose application, a significant decrease $(\mathrm{p}<0.05)$ in the level of total cholesterol and cholesterol of low density lipoprotein and some increase in the level of cholesterol of high density lipoprotein in the absence of the dynamics of triacylglycerides was established.
Conclusions. It was established that the course of lactulose application slightly reduces the level of Firmicutes, without affecting the number of bifidobacteria, increases the number of lactobacilli and through them improves some indicators of lipidogram.

Keywords: irritable bowel syndrome, microbiota, lactulose, obesity.

Стаття надійшла в редакцію 03.06.2019 р. 